\title{
Rónai Orsolya*: Az Emberi Jogok Európai Egyezménye 6. cikk 1. bekezdésének általános áttekintése az Emberi Jogok Európai Bíróságának gyakorlatára tekintettel
}

\author{
Debreceni Jogi Mühely, 2014. évi (XI. évfolyam) 1-2. szám (2014. június 30.)
}

\section{Bevezetés}

Liberté-égalité-fraternité, ahogy az 1789-es Deklaráció és a francia forradalom híres mondása tartja. Az idézett XVIII. századi időszak gyökeres változásokat hozott magával, amelyek közül az ember alapvető és elidegeníthetetlen politikai és polgári szabadságjogait emelhetjük ki. Kezdetben az ún. első generációs jogokat[1] szabályozták. Az államok passzív magatartással igyekeztek és igyekeznek napjainkban ezeket a jogokat biztosítani az emberek számára azzal, hogy tételes alapjogi katalógusokat hoznak létre és speciális eljárási szabályokat és eljárásokat határoznak meg, amellyel az esetleges alapjogi sérelmek orvosolhatóak. Napjainkban egy igen széleskörü alapjogi katalógus létezik és az élet csaknem minden területére kihatással vannak, ám ez nem mindig volt így. A jogok jelentőségének és kulcsfontosságú elemeinek a bemutatása nehéz és összetett feladat, hiszen az ezeket szabályozó jogforrások nagyon sokfélék. A szabályozás összetettségét mutatja, hogy nemzetközi szinten, az európai unió szintjén és nemzeti szinten is szabályozzák a különféle generációs tartozó jogokat.

A nemzetközi szerződések mind nemzetközi, mind pedig területi, regionális szinten szabályozzák és érvényre juttatják az eljárási alapjogokat.[2] Az emberi jogok területi védelménél számunkra az európai jogvédelem a kiemelendő, ezen belül pedig két jogi dokumentumot, kell kiemelnünk: az Emberi Jogok Európai Egyezményét[3] (a továbbiakban: EJEE) és az Európai Unió Alapjogi Chartáját[4].

A tanulmányomban az EJEE szabályanyagát vizsgáltam meg, ezért a továbbiakban a szerződéssel és annak, a címben megjelölt 6. cikke (1) bekezdésével foglalkozom. Az EJEE 6. cikke a tisztességes eljáráshoz való jogot tartalmazza. Az (1) bekezdésben az egyezmény konjunktív felsorolást tartalmaz az alapjog legfontosabb elemeiröl: (1) tisztességes és nyilvános tárgyalás tartása; (2) ésszerü időn belül; (3) törvény által létrehozott független és pártatlan bíróság által; (4) végül pedig az eljárásban meghozott ítéletet nyilvánosan kell kihirdetni[5]. A cikk a jogállamiság követelményét jeleníti meg, amely alapján minden társadalom és állam létrejön, valamint müködik. A statisztikák szerint a 6. cikk az a része az egyezménynek, amelyre a legtöbbet hivatkoznak a felek EJEB előtt.[6] Ugyanakkor a feleken kívül (felperes és alperes) más személyek nem hivatkozhatnak a cikkre, az ő esetükben a bíróság csak garantálja a tisztességes eljáráshoz való jog érvényesülését a teljes eljárás folyamatában.[7]

II. A 6. cikk (1) bekezdés megfelelő értelmezése

A Bíróság hosszú évek óta csiszolja a gyakorlati tapasztalatai alapján a cikk tényleges tartalmát arra tekintettel, hogy a jogvédelem minél hatásosabban megvalósulhasson (a hatékonyság alapelve) a gyakorlatban, így jól látható, hogy a fórum a gyakorlati igazolásra helyezi a hangsúlyt az elvont, jogtudományi és jogdogmatikai értelmezés helyett.[8]Ennek fényében, a 6. cikk alapján az EJEB számos részelemét tartotta levezethetőnek a tisztességes eljáráshoz való jognak, úgy mint:a birósághoz fordulás jogát[9], az itéletek végrehajtásához való jogot[10], és a jogerős birósági döntésekhez való jogot[11].

A cikk értelmezése során nemcsak a jelen tapasztalataira, jelenségeire kell figyelemmel lenni, hanem a korábban érvényes gazdasági és társadalmi megoldásokra, gyakorlatokra. Ezen elv kapcsán szokta a szakirodalom az egyezményt élö organizmusként emlegetni.[12] E mellett a Bíróság figyelembe veszi a szerződéses államok között alkalmazandó nemzetközi jog alapelveit és releváns szabályait.[13] 
Az egyezményhez félként csatlakozott államok nemzeti jogrendszereiben - egyaránt az anyagi és eljárásjogi szabályokban is - jelentős autonómiát élvez a 6. cikk.[14] Ez azt jelenti, hogy a nemzeti jog szabályai által eljárási hibaként értelmezett gyakorlat, cselekmény nem feltétlenül jelenti a 6. cikk megsértését.[15] Annak érdekében, hogy a Bíróság megállapításait a tagállamok könnyebben elfogadják, a fórum - az értelmezés kapcsán - alkalmanként próbál a nemzeti jogszabályokra, így különösen az alkotmányos szabályokra hivatkozni, amelyek hasonlóak, vagy akár azonosak a 6. cikk rendelkezéseivel.[16] A cikkből a kérelmezőre vonatkozó feltételrendszert is kibonthatónak találta az EJEB. E szerint az elé került ügyekben a fórum azt is megvizsgálja, hogy a kérelmező számára bőséges lehetőség kínálkozott-e arra, hogy az ügyével a megfelelő fórumhoz fordulhasson, a bíróságon meg volt-e arra a lehetősége, hogy ügyét előadhassa, vagy azt is, hogy a kérelmező számára biztosította-e a fórum azt a jogot, hogy az általa hamisnak tartott bizonyíték(ok) valóságalapját vitathassa. Fontos látni, hogy ezekben az esetekben nem arról van szó, hogy a kérelmező a nemzeti bíróság által meghozott ítéleteket támadja meg azon az alapon, hogy szerinte azt miért jó, vagy rossz döntés.[17]

A szubszidiaritás elvének megfelelően a cikk nem biztosítja azt a lehetőséget a Bíróságnak, hogy mint rendes bíróság az ítélet alapjául szolgáló tényállást újra megállapítsa, vagy nem vizsgálhatja meg azt sem, hogy a nemzeti jog megsértése megalapozott-e[18], továbbá azt sem döntheti el, hogyan kellett volna eredetileg az eljárásban előterjesztett bizonyítékokat értékelni.[19] Azonban az elmúlt években a Bíróság számtalanszor állapította meg a 6. cikk megsértését akár ugyanazon problémakör tekintetében, sőt ugyanannál a fellebbviteli bíróságnál is[20], vagy bíróságoknál, amelyek a fellebbezés tárgyában döntöttek[21]. Ilyen ügyek tekintetében a Bíróság megállapította és hangsúlyozta, hogy az ítéletek különbözéségének mélyreható jellege tág értelemben sérti a jogbiztonság követelményét. Ugyanakkor a Nagy Kamara értelmezése alapján nem a Bíróság feladatának minősül - az EJEE 6. cikke értelmében -, hogy az egyes nemzeti bíróságok különféle döntéseit összehasonlítsa[22]. Természetesen ez az eset nem állja meg a helyét, ha önkényes bírói döntés születik meg.[23]

A Bíróság tevékenysége során a nemzeti bíróságok döntéseiből indul ki, amelynél vélelmezi a nacionális bíróságok által megállapított tényállás valóságát, kivéve azokat az eseteket, amikor a nemzeti bíróság által lefolytatott eljárás sérti az egyezmény 6. cikkét.[24] Ez alapján megállapítható, hogy a tisztességes eljárás követelményét a Bíróság a korábban lefolytatott eljárás egészét tekintve vizsgálja, így egy önmagában álló, az eljárás teljes hosszától független, apró eljárási hibát nem értékel külön abból a szempontból, hogy megsértette-e az a 6. cikket.

Főszabály szerint megállapíthatjuk, hogy a 6. cikk megsértését csak a már lefolytatott, befejezett eljárások tekintetében állapíthatja meg a Bíróság, abban az esetben, ha valamelyik peres fél, akár részben is, de jogerösen elveszíttette a polgári pert. Kivételes esetekben, így a bírósághoz fordulás jogának, vagy az ésszerü idő követelménynek a megsértése előfordulhat végső, jogerős döntés nélkül is.

A 6. cikkben rögzített eljárási alapjogokról a Bíróság megállapította, hogy bizonyos elemek mint a bírósághoz fordulás joga[25] is - hasonlóságot mutat az Egyezmény 8-11. cikkével. Így a fórum meghatározta, hogy a 6. cikk alapján megvalósuló jogsértéseket nem lehet szűken értelmezni, hanem épp ellenkezőleg az Egyezmény egész szellemiségéből kell kiindulni, és a kérdéses eset összes körülményeit kell górcső alá venni. Ennek megfelelően a legtöbb esetnél a Bíróság az ún. sui generis arányosság tesztet alkalmazza, amelyet gyakran neveznek az alapjog lényegi tesztjének.[26]

III. A cikk alkalmazhatósága 
Az EJEE 1. cikke szerint a részes államoknak kötelessége a 6. cikkhez megfelelöen harmonizálni a belső jogrendszereiket. Mivel ez számukra kötelesség, nem lehet akár pénzügyi vagy gyakorlati nehézségekre hivatkozással nem teljesíteni a cikkben elöírtakat.[27] İgy minden szerződéses államnak biztosítani kell eljárási jogában a tisztességes eljáráshoz való jog megvalósulását. A szabályozás kialakításakor elsődlegesen a 6 . cikk rendelkezéseire, másodlagosan a Bíróság esetjogára kell tekintettel lenni.

A 6. cikk önálló értelmezésének elve alapján az Emberi Jogok Európai Bírósága polgári ügyekben, polgári jogi jogok és kötelezettségeket érintően dönt a cikk alkalmazhatóságáról.[28] A 6. cikk alkalmazhatósága a bírósági tárgyalás előtti, a fellebbezési és egyéb jogorvoslati eljárásokban nem alapozható az önálló értelmezés követelményére, hanem az a nemzeti jogrendszerekben meglévő jogorvoslati eljárások függvénye.[29] Ahhoz, hogy a 6. cikk rendelkezéseit a polgári eljárásokban alkalmazni lehessen, számos követelménynek kell megvalósulnia:

1. jogokat és kötelezettségeket érintö jogvitának kell lennie;[30]

2. a kérdéses jogot és kötelezettséget nemzeti jogszabálynak kell tartalmaznia;[31]

3. a kérdéses jognak és kötelezettségnek magánjogi természetűnek kell lennie.[32]

\section{III.1. A Benthem-kritériumok}

Az első pontban megjelölt három követelményt a szakirodalom összefoglalóan Benthemkritériumokként is nevezi. A jogvitának evidens módon valamilyen jogot, vagy kötelezettséget érintőnek kell lenni, amelyet a nemzeti jogszabályok határoznak meg. A Benthemkritériumoknak megfelelően szükséges, hogy fennálljon:

1. a jogokat vagy kötelezettséget az anyagi jogszabályoknak megfelelöen kell értelmezni, nem pedig eljárási jellegük szerint;

2. ezeket tágan kell interpretálni, nem pedig csakis a szük értelemben vett jelentésre kell koncentrálni az értelmezés során;

3. ténybeli és jogi kérdéseket érinthetnek a jogok, vagy kötelezettségek;

4. valósnak és komolynak kell lenniük;

5. a felperes jogai szempontjából kell meghatározónak lenniük, azokkal szoros kapcsolatban kell állniuk.

III.2. A jogvita és a nemzeti jogszabály által meghatározott jogok

A nemzeti jogszabályok által meghatározott jogvita az okozatiság alapján maga után vonja automatikusan a nemzeti jogszabályok által meghatározott vitatható követelés fogalmát, amely követelésen a jogvita alapszik.[33] A jogok tekintetében nem elegendő feltétel az, ha inabstracto léteznek, hiszen a felperesnek kötelessége, hogy valamiféle ok-okozati összefüggést mutasson fel a jog és az érvényesített követelés fennállása között a hazai peres eljárásokban.

Összegzésként meghatározhatjuk azon jogviták katalógusát, amelyek a nemzeti jogszabályok szerint meghatározott jogokon alapulnak:

- gázellátó berendezés telepítésére és hosszú távú müködtetésére szolgáló engedély kiadásának a megtagadása;[34]

- az ügyvéd határidőn túl érvényesített követelése az ügyvédi kamarába történő visszavétele iránt;[35]

- a praxis jog ideiglenes felfüggesztése;[36]

- a külföldi medikus követelése, hogy más országban regisztrált orvos lehessen;[37]

- a jogellenes fogva tartásból származó károk megtérítése iránti igény;[38] 
- névváltoztatás iránti eljárás, tekintet nélküla nemzeti jogszabályok által a közigazgatási hatóságoknak biztosított diszkréciós jogkörére, amely értelmében eldönthetik, hogy az érintett félnek van-e kereshetőségi joga, avagy sem;[39] etc.

Természetesen azon jogvitákat is meg kell határoznunk, ahol a Benthemkritériumok nem állnak fent, vagyis nem beszélhetünk a nemzeti jogszabályok által meghatározott jogokon alapuló jogvitákról:

- iskolai, vagy egyetemi vizsgálathoz hasonlítható újraértékelési eljárás, amelynek a tárgya meghatározott szakmai végzettség;[40]

- a kérelmezők lakóhelyéhez közel megépíteni tervezett atomerőmü müködésének megakadályozása;[41]

- egy repülötér bővítését megengedő, kétoldalú megállapodást közzétevő elnöki rendelet megtámadása arra hivatkozással, hogy a tervezett munkálatok sértik a felperesek üzleti és vagyoni érdekeiket;[42]

- a helyi biztosító intézetnél közzétett egészségügyi dokumentációk nyilvánosságra hozatalát támadó igények;[43]

- a kisebb szabálysértések iránti jogsegély elutasítása iránti igény, annak ellenére, hogy ezeket az igényeket a nemzeti jogszabály ilyen alapon megengedi;[44]

- a helyi repülőtér zajszennyezése által okozott károk megtérítése, amelynek a hazai jogban nincsen jogszabályi alapja;[45] etc.

A nemzeti jogrendszerek tekintetében a jogállamiság alapvető elvét sértené, ha a polgári jogi jogviták tárgyát csakis bizonyos követelésekre szükítenénk, vagy csak bizonyos személyek polgári jogi felelősségét lehetne megállapítani, így ez a szükítés nemzeti szinten nem képzelhető el.[46] A Bíróság ahhoz, hogy a nemzeti anyagi jogokat érintő döntésektől eltérjen az eljárásában komoly érvekre van szüksége, hiszen a döntéseket akár a részes államok legfelsőbb bírói fórumai is meghozhatják. A nemzeti jogrendszabályokban a 6 . cikkjelentős, de nem teljes autonómiát élvez.[47]

III.3. A jogok és kötelezettség polgári jogi jellege

A polgári jogok és kötelezettségek fogalma független a nemzeti jogrendszerek által determinált fogalomtól.[48] A 6. cikk a felektől és a jogvitára vonatkozó jogalkotás természetétől függetlenül alkalmazandó, hiszen ami ebböl a szempontból releváns az a kérdéses jog karaktere és az, hogy a jogvita végén meghozott döntés közvetlenül érinti-e a kérdéses polgári jogi jogot és kötelezettséget.[49]

A jog vagyoni jellegü természete fontos, de nem döntő érv a 6. cikk alkalmazhatóságának a kérdésében. A jogvitának legalább vagyoni természetünek kell lennie és jogsértésen kell alapulnia egyszerre, vagyis összességben vagyoni jogi jellegünek kell lennie.[50] Azonban fontos látni, hogy a kérelmező vagyoni természetű sérelme alapján megindult eljárás nem mindig jelent polgári jogi jogvitát.[51] Ahhoz, hogy a jogvita polgári jogi lehessen a magánjogi (így polgári jogi) elemeknek többségben kell lennie a közjogi elemekhez képest.[52] Ugyanakkor a büntető jogi jogsértésekre kialakult egységes fogalommal szemben nem beszélhetünk egységes polgári jogi jogvita fogalomról, azokat csak az adott esetben tudjuk megállapítani.[53] Felsorolás jelleggel, polgári jogi jogvitának minősül:

- a magánjogi felek közötti jogviták, mint a károkozások, a kötelmi jogi és családjogi jogviták;

- ahhoz való jogosultság, hogy valaki szellemi foglalkozást folytasson, mint például orvosként praktizáljon[54], könyvelöként[55] vagy ügyvédként dolgozzon[56];

- közigazgatási határozattal szabályozott gazdasági tevékenység folytatása, mint például taxizás[57], gázellátó rendszerek telepítése[58], alkohol felszolgálása[59], vagy akár kavicsbányában folytatott munka;[60]

- nyugdíj viszonnyal és egyéb szociális jellegű juttatásokkal kapcsolatos jogviták;[61] 
- olyan kártérítési ügy, amelyet a hatóságok a volt polgármesterrel szemben indítottak meg a közpénzek hütlen kezelése miatt, hiszen ezzel kárt okozott a közösségnek a volt polgármester;[62]

- a munkajogi jogviták, beleértve a munkaviszony megszünésével és a fizetéssel kapcsolatos jogvitákat;[63] etc.

Hosszú éveken keresztül, a 6. cikk tárgyi hatálya alól a szolgáltatásokhoz való hozzáférés, a jogellenes felmondás, vagy a köztisztviselök (akik az állami hatalom letéteményeseként müködnek) hivatalba történő visszahelyezése ki voltak zárva.[64] Azonban a 2007-es Vilho Eskelinen és mások v. Finnország [Nagy Kamara] döntés[65] óta a munkaügyi kérdésekkel kapcsolatos jogvitákat[66] polgári joginak minősítette és szintén annak tekintette azokat a kérdéseket, ahol a nemzeti jogalkotó bizonyos csoportok számára lehetővé teszi a bírósághoz fordulást, még akkor is, ha az egyetlen fórum, akihez a kérelmezö fordulhat az Alkotmánybíróság.[67] Így a Bíróság további ügyeket határozott meg, amelyek polgári jogvitának minősülnek:

- a kormányzati ellenőrök által vizsgált üzletátvétel, annak ellenére, ha ez a jelentés sérti a felperes jó hírnevét;[68]

- belső közigazgatási döntésekkel kapcsolatos jogviták, amelyek nemzetközi szervezetet érintenek, nevezetesen a Nemzetközi Szabadalmi Hivatalt;[69]

- a Schengeni Információs Rendszerben rögzített személyes adatok helyesbítése iránti eljárás;[70]

- az evangélikus egyházon belüli pap áthelyezések egyik plébániáról a másikra;[71]

- a menedék jogosult kérelmének megtagadásával okozott károk;[72] etc.

\section{Záró gondolatok}

Az egyezmény 6. cikke a legjelentősebb és egyben a legkomplexebb része az EJEE-nek. Ennek köszönhetően a legtöbbet hivatkozott pontja is. Napjainkban a jelentősége folyamatosan fokozódik. A legfrissebb hírek szerint az egyezménnyel kapcsolatban érdemes megemlíteni az Európai Unió helyzetét. A Lisszaboni Szerződés óta az Európai Unió Alapjogi Chartája az egyik legfontosabb jogi dokumentuma lett az EU-nak vagy, hogy még pontosabbak legyünk 2009-óta elsődleges jogforrása. Ez azt jelenti, hogy 2009-től jogilag kötelező érvényű jogforrása az Európai Uniónak, amely a tagállamok számára számos kötelezettséget határoz meg: egyrészt a nemzeti jogszabályokat harmonizálniuk kell a Chartával, a kérelmezö/felperes hivatkozhat rá a jogvitákban, és a bíróságok az ítélkező tevékenységük során kötelesek a Charta elöírásait betartani. A kérdés ezzel kapcsolatban alapvetően az, hogy ha a tagállamok részesei az EJEE-nek, akkor az EU miért nem az, miért kell a jogi személynek egy másik - de tartalmában hasonló - dokumentumot elfogadnia és kötelező erejüvé tennie. A legfrissebb jelentések alapján az EU 3 éve elindította a csatlakozási eljárást az egyezményhez és jelenleg az utolsó lépésnél tart a csatlakozásban, így az uniós polgárok számára két út jelenik meg az alapjogvédelem területén: az EJEE alapján felállított Európai Emberi Jogi Bíróság, mint kontrollmechanizmus és a Charta alapján ítélkező Európai Unió Bírósága.

\section{A general overview of the article 6 paragraph 1 of the European Convention on Human Rights based on the case law of the European Court of Human Rights - Summary}

The most important human rights were firstly defined by the French Declaration from 1789. These rights are called as first generation rights, because they guarantee the most important civil and political rights of people. The states mostly act passive in order to protect them. They create acts on their protection, special mechanisms for enforcing them. We can state that every field of law is based upon them and helps protecting the human rights. 
The right to a fair trial is a first generation human right. Its regulation scheme is very complex; therefore it is a hard and a complex task to define the importance and the key functions of this right, because the laws on it are varied. Besides civil procedural law, international law, EU-law and - within national legal systems - constitutional law has also been dealing with the right to a fair trial.

In the field of international law many international and regional treaties exist on the enforcement of procedural rights. In my paper I examined the European Convention on Human Rights (hereinafter: ECHR). The ECHR is an international treaty on the protection of human rights. It was born under the auspices of the Council of Europe in 1950, Rome. From 1959 its control mechanism is the European Court of Human Rights.

In my paper I examined the proper interpretation and the actual application of the ECHR art. 6. par. 1based on the work of the international court.The article 6 of ECHR is about the right to a fair trial. In par. 1 the Convention gives a list of the most common features of a fair trial: (1) a fair and public hearing; (2) with a reasonable time; (3) the tribunal must be established by law and must meet with the requirements of independency and impartiality; (4) and finally the judgement shall be pronounced publicly. It enshrines the principle of the rule of law, upon which such a society is based and built.

The first chapter deals with problem of the interpretation of the article. I tried to give the most convenient statements, which I defined upon the case law of the ECHR. After the question of interpretation is answered, the third chapter tries to give an overview of the applicability of article 6.In this section I cited many cases of the ECHR, because the Court has been developing the question of applicability in its case law. It is because it considers the Convention as a living-organism, so the article 6 . needed to be interpreted again and again during these decades.

* Dr. Rónai Orsolya I. éves a Miskolci Egyetem Állam-és Jogtudományi Karának Deák Ferenc Doktori Iskolájában. Kutatási témája a polgári eljárásjog alapjogainak érvényesíthetősége az Európai Unióban.

[1] A tisztességes eljáráshoz való jog is első generációs alapjognak minősül.

[2] Az említett egyezmények nemzetközi és regionális szinten szabályozzák az emberi jogokat, amelyekről adnak egy részletes listát, valamint minden egyezmény rendelkezik a saját kontroll mechanizmusával.

[3] Az Európa Tanács égisze alatt 1950-ben, Rómában született meg az egyezmény. 1959-től kezdve az Emberi Jogok Európai Bírósága (továbbiakban: EJEB) látja el a jogvédelmet, vagy, ahogy a hétköznapi nyelv nevezi a Strasbourgi Bíróság.

[4] 2000/C 364/01. A Chartát először 2000-ben fogadta el a Parlament, a Tanács és a Bizottság Nizzában. Később egy módosítást követően 2007-ben fogadták el és hirdették ki ismét.

[5] Alapelvi szinten mindenkinek joga van a nyilvános tárgyaláshoz, de egyes esetekben a nyilvánosságot ki lehet zárni annak érdekében, hogy a peres felek jogvédelme megvalósuljon. A nyilvánosság kizárásának az okait szintén az egyes pont tartalmazza. E szerint a bíróság kizárhatja a nyilvánosságot, amennyiben egy demokratikus társadalomban ez az erkölcsök, a közrend, illetőleg a nemzetbiztonság érdekében szükséges, ha e korlátozás kiskorúak érdekei, vagy az eljárásban résztvevő felek magánéletének védelme szempontjából szükséges, illetőleg annyiban, amennyiben ezt a bíróság feltétlenül szükségesnek tartja, mert úgy ítéli meg, hogy az adott ügyben olyan különleges körülmények állnak fent, melyek folytán a nyilvánosság az igazságszolgáltatás érdekeit akár az egész eljárásban, vagy annak bizonyos részében veszélyeztetné. 
[6] Right to a fair trialunderthe European Convention of Human Rights (Article 6). IntherightsManualforLawyers. 2009. 1. p.

[7] Mihova v. Olaszország, Ügyszám25000/07.

[8] Sakhnovski v. Oroszország [Nagy Kamara], Ügyszám:21272/03. 99-107. §§

[9] Golderv. az Egyesült Királyság, Ügyszám: 4451/70. 26-40. §§

[10] Hornsby v. Görögország, Ügyszám: 18357/91. 40-45. §§

[11] Brumărescu v. Románia, Ügyszám: 28342/95. 60-65. §§

[12] Marckxv. Belgium, Ügyszám: 6833/74. 41. §

[13] DemirésBaykara v. Törökország [Nagy Kamara], Ügyszám: 34503/97. 76-84. §§

[14] Khanv.az Egyesült Királyság, Ügyszám: 35394/97. 34-40. §§

[15] Az alkalmazhatósági teszthez (Roche v. az Egyesült Királyság [Nagy Kamara], Ügyszám: 32555/96. 116-126.\$§)a Bíróság mindig tágan értelmezte a nemzeti jogszabályokat, és néhány eset tekintetében a cikk megalapozottságának vizsgálatakor igyekezett figyelemmel lenni az akkuzatórius és inkvizitórius eljárásokban a bizonyítási teher szabályozási különbözőségére, így amikor a Bíróság a kontinentális jogrendszerek tekintetében, a bírói mérlegelési jogkör kapcsán úgy döntött, hogy azt kell tágan értelmezni, amikor azt kell eldönteni, hogy melyik tanút hallgassák meg a tanúbizonyítást, mint bizonyítási eszköz tekintetében (Vidal v. Belgium, Ügyszám:12351/86.32-35. $\S \S$ )

[16] Henryk Urban ésRyszard Urban v. Lengyelország, Ügyszám: 23614/08. 47-56. §§

[17] Karalevičius v. Litvánia, Ügyszám: 53254/99.

[18] Bernard v. Franciaország, Ügyszám: 22885/93. 37-41. §§

[19] Schenk v. Svájc, Ügyszám: 10862/84. 45-49. §§

[20] Tudor Tudor v. Románia, Ügyszám: 29035/05. 26-33. §§

[21] Ştefănică és mások v. Románia, Ügyszám: 38155/02. 31-40. §§

[22] Abban az esetben természetesen, ha hasonló eljárási keretek között születnek hasonló döntések.

[23] NejdetŞahin ésPerihanŞahin v. Törökország [Nagy Kamara], Ügyszám: 13279/05. 59-96. $\S \S$

[24] Ramanauskas v. Litvánia [Nagy Kamara], Ügyszám: 74420/01. 48-74. §§

[25] Ashingdane v. az Egyesült Királyság, Ügyszám: 8225/78. 55-60. §§

[26] Például ide sorolható az az eset is, amikor a polgári ügyekben alacsonyabb szinten szabályozták a fegyverek egyenlöségét a büntetö ügyekhez képest. Például: Foucher v. Franciaország, Ügyszám: 22209/93. 29-38. $\quad \xi \oint$ összevetve $\quad$ a Menet v. Franciaország, Ügyszám: 39553/02. 43-53. §§ üggyel.

[27] Salesi v. Olaszország, Ügyszám: 13023/87. 24. §

[28] Ringeisen v. Ausztria, Ügyszám: 2614/65. 94. §

[29] Delcourt v. Belgium, Ügyszám: 2689/65. 23-26. §§

[30] Benthem v. Hollandia, Ügyszám: 8848/80. 32-36. §§

[31] Lásd továbbá a 16. lábjegyzetben feltüntetett forrást116-126. §§

[32] Ringeisen v. Ausztria, Ügyszám: 2614/65.94. §

[33] Georgiadis v. Görögország, Ügyszám:21522/93. 27-36. §§

[34] Lásd továbbá a 28. lábjegyzetben feltüntetett forrást.

[35] H. v.Belgium, Ügyszám: 8950/80.

[36] Le Compte, Van Leuvenés De Meyere v. Belgium, Ügyszám: 6878/75. és 7238/75.

[37] Chevrolv. Franciaország, Ügyszám: 49636/99.

[38] Georgiadis v. Görögország, Ügyszám: 21522/93.

[39] Mustafa v. Franciaország, Ügyszám: 63056/00.

[40] Van Marle v. Hollandia, Ügyszám: 8685/79.

[41] Balmer-Schafroth és mások v. Svédország [Nagy Kamara], Ügyszám: 22110/93.

[42] Sarl du Parc d'activites de Blotzheim v. Franciaország, Ügyszám: 723777/01. 
[43] M.S. v. Svédország, Ügyszám: 20837/92.

[44] Gutfreund v. Franciaország, Ügyszám: 45681/99.

[45] Powell ésRayner v. az Egyesült Királyság, Ügyszám: 9310/81.

[46] Osmanv.az Egyesült Királyság, Ügyszám:23452/94. 136-140. §§

[47] Lásd továbbá a 16. lábjegyzetben feltüntetett forrást.

[48] Lásd továbbá a 35. lábjegyzetben feltüntetett forrást.

[49] Baraona v. Portugália, Ügyszám:10092/82. 38-44. §§

[50] Procola v. Luxemburg, Ügyszám:14570/89.37-40. §§

[51] Panjeheighalehei v. Dánia, Ügyszám: 11230/07.

[52] Deumeland v. Németország, Ügyszám:9384/81. 59-74. §§

[53] Engel ésmások v. Hollandia, Ügyszám: 5370/72.

[54] Koenig v. Németország, Ügyszám: 6232/73.

[55] Lásd továbbá a 39. lábjegyzetben feltüntetett forrást.

[56] Lásd továbbá a 34. lábjegyzetben feltüntetett forrást.

[57] Pudas v. Svédország, Ügyszám: 10426/83.

[58] Lásd továbbá a 28. lábjegyzetben feltüntetett forrást.

[59] TreTraktorer AB v. Svédország, Ügyszám: 10873/84.

[60] Fredin v. Svédország, Ügyszám: 12033/86.

[61] Salesi v. Olaszország, Ügyszám:13023/87.

[62] Richard-Dubarry v. Franciaország, Ügyszám:53929/00.

[63] Kabkov v. Oroszország, Ügyszám: 12377/03.

[64] Pellegrin v. Franciaország [Nagy Kamara], Ügyszám: 28541/95. 64-71. §§

[65] Ügyszám: 63235/00.

[66] Például: fizetések, juttatások kérdése... etc.

[67] Olujić v. Horvátország, Ügyszám:22330/05. 31-43. §§

[68] Fayed v. az Egyesült Királyság, Ügyszám: 17101/90.

[69] Rambus Inc. v. Németország, Ügyszám: 40382/04.

[70] Dalea v. Franciaország, Ügyszám: 964/04.

[71] Ahtinen v. Finnország, Ügyszám: 48907/99.

[72] Lásd továbbá a 41. lábjegyzetben feltüntetett forrást. 